M. Duong*, A.M. Wilson", L. Jayaram*, M. Dolovich* and F. Hargreave*

*Asthma Research Group, Firestone Institute for Respiratory Health, St Joseph's Healthcare and Hamilton Health Sciences, McMaster University, Hamilton, ON, Canada, and "School of Medicine, Health Policy and Practice University of East Anglia, Norwich, UK.

\section{STATEMENT OF INTEREST}

None declared.

\section{ACKNOWLEDGEMENTS}

The authors would like to thank M. Morris, P. Hussack, A. Efthimiadis and S. Evans (The Firestone Institute for Respiratory Health, St Joseph's Hospital, McMaster University, Hamilton, ON, Canada) for their assistance in the conduct of the trial and sputum processing.

\section{REFERENCES}

1 da Costa JC, Olsen PC, de Azeredo Siqueira R, et al. JMF2-1, a lidocaine derivative acting on airways spasm and lung allergic inflammation in rats. J Allergy Clin Immunol 2007; 119: 219-225.

2 Okada S, Hagan JB, Kato M, et al. Lidocaine and its analogues inhibit IL-5-mediated survival and activation of human eosinophils. J Immunol 1998; 160: 4010-4017.
3 Kai T, Nishimura J, Kobayashi S, Takahashi S, Yoshitake J, Kanaide H. Effects of lidocaine on intracellular $\mathrm{Ca}^{2+}$ and tension in airway smooth muscle. Anesthesiology 1993; 78: 945-965.

4 Hunt LW, Swedlund HA, Gleich GJ. Effect of nebulized lidocaine on severe glucocorticoid-dependent asthma. Mayo Clin Proc 1996; 71: 361-368.

5 Hunt LW, Frigas EF, Butterfield JH, et al. Treatment of asthma with nebulized lidocaine: a randomized, placebocontrolled study. J Allergy Clin Immunol 2004; 113: 853-859.

6 Pizzichini E, Pizzichini MMM, Efthimiadis A, et al. Indices of airway inflammation in induced sputum: reproducibility and validity of cell and fluid-phase measurements. Am J Respir Crit Care Med 1996; 154: 308-317.

7 Decco ML, Neeno TA, Hunt LW, O'Connell EJ, Yunginger JW, Sachs MI. Nebulized lidocaine in the treatment of severe asthma in children: a pilot study. Ann Allergy Asthma Immunol 1999; 82: 29-32.

8 Holgate ST, Polosa R. The mechanisms, diagnosis, and management of severe asthma in adults. Lancet 2006; 368: 780-793.

9 Wenzel S. Severe asthma in adults. Am J Respir Crit Care Med 2005; 172: 149-160.

10 Chang HY, Togias A, Brown RH. The effects of systemic lidocaine on airway tone and pulmonary function in asthmatic subjects. Anesth Analg 2007; 104: 1109-1115.

DOI: 10.1183/09031936.00087108

\title{
Dental units as infection sources of Pseudomonas aeruginosa
}

\section{To the Editors:}

In a recent issue of the European Respiratory Journal, we read with interest the article by SCHELSTRAETE et al. [1] about Pseudomonas aeruginosa in the home environment of newly infected patients with cystic fibrosis (CF). Based on the study results, SCHELSTRAETE et al. [1] suggest that neither home environment nor other patients are important sources of $P$. aeruginosa infection; therefore, the question remains as to the actual source of an initial infection. They conclude that acquisition from the environment outside the home is probable.

One possible source could be aerosol exposition of contaminated water during dental treatment. Transmission of microbial pathogens to patients from water in dental chair units (DCUs) has been a concern for many years. In the early 1980s, a German study revealed $P$. aeruginosa in $74 \%$ (29 out 39 patients) of the investigated DCUs in private dental practices; however, the findings were not widely noticed as it was published in German [2]. Bacterial biofilm formation in DCU waterlines is a widespread problem and poses a potential risk of infection to dental staff and patients, particularly those who are medically compromised, i.e. with CF or immunocompromised [3, 4]. Therefore, different measures of disinfection have been introduced to improve the hygiene in dental units and guidelines for infection control in dental healthcare settings have been published [5]. In spite of these measures, $P$. aeruginos a can still be frequently found in water of DCUs. We have recently investigated the prevalence of $P$. aeruginosa and the total bacterial count (all aerobic mesophilic bacteria measured as colony forming units (CFU)) in the water of DCUs in the area of St. Gallen (Switzerland). In total, water from 76 dental units was collected either from turbine tube, multifunction syringe or micromotor early on a Monday morning before the instruments were used. After using the DCU for $\geqslant 2 \mathrm{~h}$, water was collected for a second time. All specimens were immediately transported to the Environmental Health Department (St. Gallen) and examined within $24 \mathrm{~h}$ of collection, as described in a previous study [6]. P. aeruginosa was found in seven $(9 \%)$ out of 76 DCUs from the first sample collection and only one was negative after using the DCU for $\geqslant 24 \mathrm{~h}$. Increased total bacterial count $\left(>300 \mathrm{CFU} \cdot \mathrm{mL}^{-1}\right)$ was found in $60 \%$ (46 out of 76) of the DCUs in the first probe, which decreased to $38 \%$ (29 out of 76 ) after using the unit for $\geqslant 2 \mathrm{~h}$. Legionella spp. were found in $20 \%$ (15 out of 76 ) of both collected specimens. All dentists gave reassurance that they follow the manufacturers' disinfection recommendations.

The bacteria that contaminate the dental chair unit waterlines can originate from two places. First, municipal water piped 
into the dental chair unit and, secondly, suck back of patient's saliva into the line due to lack of anti-retraction valves. Even a small amount of Pseudomonas aeruginosa in a municipal water system can contribute to the dental chair unit contamination problem because dental chair units provide a different environment with small bores, narrow lumens and periods of stagnant water. However, if the water is well maintained according to current hygiene guidelines, the prevalence of Pseudomonas aeruginosa in the public water supply is extremely low [6]. As Pseudomonas aeruginosa can be recovered from the oral cavity of $\sim 4 \%$ of healthy individuals [7], it is therefore possible that some of these bacteria are aspirated into the dental chair unit waterlines through a defective check valve and are able to colonise in the waterlines. As the suction system hoses and pipe work are frequently wet, they provide an environment that is conducive to the growth and proliferation of biofilms which adhere to the inner surfaces of the lines. This biofilm protects the bacteria both from being washed away by the water flow and from many types of antimicrobial water treatment [8].

\section{J. Barben* and J. Schmid}

*Dept of Paediatric Pulmonology and CF Centre, Children's Hospital, and "Public Health and Consumer Protection Agency, St. Gallen, Switzerland.

\section{STATEMENT OF INTEREST}

None declared.

\section{REFERENCES}

1 Schelstraete P, Van Daele S, De Boeck K, et al. Pseudomonas aeruginosa in the home environment of newly infected cystic fibrosis patients. Eur Respir J 2008; 31: 822-829.

2 Exner M, Haun F, Kocikowski R. Zahnärztliche Einheiten als Kontaminationsquelle für Pseudomonas aeruginosa. [Dental units as sources of contamination by Pseudomonas aeruginosa]. Dtsch Zahnarztl Z 1981; 36: 819-824.

3 Barbeau J, Gauthier C, Payment P. Biofilms, infectious agents, and dental unit waterlines: a review. Can J Microbiol 1998; 44: 1019-1028.

4 Walker JT, Bradshaw DJ, Bennett AM, Fulford MR, Martin MV, Marsh PD. Microbial biofilm formation and contamination of dental-unit water systems in general dental practice. Appl Environ Microbiol 2000; 66: 3363-3367.

5 Kohn WG, Collins AS, Cleveland JL, et al. Guidelines for infection control in dental health-care settings - 2003 MMWR Recomm Rep 2003; 52: 1-61.

6 Barben J, Hafen G, Schmid J, Swiss Paediatric Respiratory Research Group. Pseudomonas aeruginosa in public swimming pools and bathroom water of patients with cystic fibrosis. J Cyst Fibros 2005; 4: 227-231.

7 Botzenhart K, Puhr OF, Döring G. [Pseudomonas aeruginosa in the oral cavity; occurance and age distribution of adult germ carriers.]. Zentralbl Bakt Mikrobiol 1985; 180: 471-479.

8 Donlan RM. Biofilms: microbial life on surfaces. Emerg Infect Dis 2002; 8: 881-890.

DOI: $10.1183 / 09031936.00072808$

\section{Impact of poor dental health on pneumonia}

\section{To the Editors:}

Pneumonia imposes a significant burden on a population, not only in terms of morbidity and mortality but also economically [1-3]. Direct costs generally increase from community-acquired pneumonia (CAP; US\$25,218), healthcare-associated pneumonia (HCAP; US $\$ 27,647$ ), hospital-acquired pneumonia (HAP; US $\$ 65,292)$ to ventilator-associated pneumonia (US\$150,841) and reflect the level of care and length of hospitalisation [1]. The prevalence of elderly patients with pneumonia admitted to hospital is rising and it has been suggested that greater effort is required to vaccinate these individuals and identify other comorbid factors [4]. Even amongst employed patients with CAP, the majority of direct costs (59\%) are attributable to a small proportion of individuals $(10 \%)$ who require hospitalisation [2]. COLICE et al. [3] estimated that even amongst working individuals, the annual cost of CAP in the USA amounted to US\$12.2 billion in 2004 .

It was therefore with great interest that we read the study by ALMIRALL et al. [5], which attempted to identify new modifiable risk factors for CAP in a general population. Uniquely for a study of CAP, the authors chose to look at indices of dental health status and found that a visit to the dentist in the previous month was protective, while dental dysaesthesia or wearing a dental prosthesis were risk factors for CAP. These associations existed even though previously identified risk factors in larger populations of CAP, such as the use of acidsuppressing drugs, were not apparent [6].

There is an accumulating body of data that implicates dental plaque as a reservoir for pulmonary infection in critical care and institutionalised elderly patients [7], and that even instituting a programme of dental hygiene can reduce episodes of HCAP [8]. The study by ALMIRALL et al. [5] has important implications for healthcare resources, particularly in the UK where there have been numerous media reports detailing patients' difficulty in accessing dental care. THOMAs et al. [9] recently analysed data on all hospital admissions in England for dental abscess drainage and found a doubling of admissions between 1998-1999 and 2005-2006. Concurrently, the number of patients registered with a National Health Service (NHS) dentist has fallen by 6 million between 1994 and 2004; more than a fifth of patients in a recent survey had declined dental treatment because of cost [9]. Provision of NHS dentists compares poorly with other European countries and is unevenly distributed, such that a quarter of the population of England and Wales are supplied with $<0.3$ NHS dentists per 